2016-04-12

\title{
Physical and Digital Integration Strategies of Electronic Device Supply Chains and Their Applicability to ETO Supply Chains
}

\author{
Claudia-Maria Wagner \\ Technological University Dublin, claudia.wagner@tudublin.ie \\ Colm Ryan \\ Technological University Dublin, cfryan01@gmail.com
}

Follow this and additional works at: https://arrow.tudublin.ie/nitlbk

Part of the Engineering Commons, and the Operations and Supply Chain Management Commons

\section{Recommended Citation}

Wagner, C. and Ryan, C. (2016) Physical and Digital Integration Strategies of Electronic Device Supply Chains and Their Applicability to ETO Supply Chains. Chapter 11 from Book entitled Supply chain strategies and the engineer-to-order approach. IGI Global 2016.

This Book Chapter is brought to you for free and open access by the National Institute for Transport and Logistics at ARROW@TU Dublin. It has been accepted for inclusion in Books/Book chapters by an authorized administrator of ARROW@TU Dublin. For more information, please contact arrow.admin@tudublin.ie, aisling.coyne@tudublin.ie,gerard.connolly@tudublin.ie.

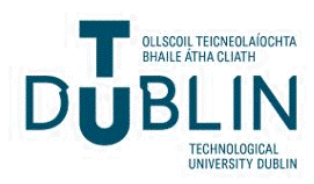




\section{Supply Chain Strategies and the Engineer-to- Order Approach}

Richard Addo-Tenkorang

University of Vaasa, Finland

Jussi Kantola

University of Vaasa, Finland

Petri Helo

University of Vaasa, Finland

Ahm Shamsuzzoha

Sultan Qaboos University, Oman

A volume in the Advances in Logistics,

Operations, and Management Science (ALOMS)

BUSINESS SCIENCE

Reference

Book Series

An Imprint of IGI Global 
Published in the United States of America by

Business Science Reference (an imprint of IGI Global)

701 E. Chocolate Avenue

Hershey PA, USA 17033

Tel: 717-533-8845

Fax: 717-533-8661

E-mail: cust@igi-global.com

Web site: http://www.igi-global.com

Copyright (C) 2016 by IGI Global. All rights reserved. No part of this publication may be reproduced, stored or distributed in any form or by any means, electronic or mechanical, including photocopying, without written permission from the publisher. Product or company names used in this set are for identification purposes only. Inclusion of the names of the products or companies does not indicate a claim of ownership by IGI Global of the trademark or registered trademark.

Library of Congress Cataloging-in-Publication Data

Names: Addo-Tenkorang, Richard, 1978- editor.

Title: Supply chain strategies and the engineer-to-order approach / Richard

Addo-Tenkorang, Jussi Kantola, Petri Helo and Ahm Shamsuzzoha, editors.

Description: Hershey, PA : Business Science Reference, [2016] I Includes

bibliographical references and index.

Identifiers: LCCN 2016002535I ISBN 9781522500216 (hardcover : alk. paper) I

ISBN 9781522500223 (ebook : alk. paper)

Subjects: LCSH: Business logistics.

Classification: LCC HD38.5 .S8962436 2016 I DDC 658.5/038--dc23 LC record available at http://lccn.loc.gov/2016002535

This book is published in the IGI Global book series Advances in Logistics, Operations, and Management Science (ALOMS) (ISSN: 2327-350X; eISSN: 2327-3518)

British Cataloguing in Publication Data

A Cataloguing in Publication record for this book is available from the British Library.

All work contributed to this book is new, previously-unpublished material. The views expressed in this book are those of the authors, but not necessarily of the publisher.

For electronic access to this publication, please contact: eresources@igi-global.com. 


\title{
Chapter 11 \\ Physical and Digital Integration Strategies of Electronic Device Supply Chains and Their Applicability to ETO Supply Chains
}

\author{
Claudia-Maria Wagner \\ Dublin Institute of Technology, Ireland \\ Colm Ryan \\ Dublin Institute of Technology, Ireland
}

\begin{abstract}
The growth in the manufacture and distribution of electronic devices presents a source of continuing innovation. Electronic devices are products that integrate physical forms (i.e. hardware) and virtual forms (e.g. software) to deliver value to customers. These forms are very different from a product design and supply chain perspective, but nevertheless they need to work closely together in order to create value for the customers. For electronic device manufacturers, it is important that processes are in place to facilitate the seamless integration of both forms throughout the engineering, production, distribution and support stages of the product lifecycle. This chapter examines the role of physical and virtual supply chain innovation strategies in electronic device supply chains by exploring the commonalities and differences between the design, manufacturing, and distribution models of digital and physical elements. It also explores to what extent such strategies can be employed for engineer-to-order (ETO) supply chains.
\end{abstract}




\section{INTRODUCTION}

One of the most significant trends over the last few years has been the massive increase in the number of electronic devices in use. Examples of such products are smart phones, tablets, watches, camcorders, vehicles and many different kinds of industrial, military and healthcare devices. The growth in the manufacture and distribution of electronic devices presents a source of continuing innovation. Electronic devices are products that integrate physical forms (i.e. hardware) and virtual forms (e.g. software) to deliver value to customers. These forms are very different from a product design and supply chain perspective, but nevertheless they need to work closely together in order to create value for the customers (Wagner \& Ryan, 2009). For electronic device manufacturers, it is important that processes are in place to facilitate the seamless integration of both forms throughout the engineering, production, distribution and support stages of the product lifecycle.

Although digital products potentially offer considerable advantages to innovators as they are less constrained by physical properties, they also present significant challenges. Hybrid approaches are explored, where the best of both worlds, physical and digital, can be applied. The merging of physical and digital elements into an integrated product creates a supply chain that is very different to a purely physical situation. Supply chain management principles of such a hybrid product approach can be derived from the concept of servitisation, which refers to the bundling of products and services into one harmonised product offering. Services and software are two very much overlapping concepts. Typically, in a hybrid product bundle, software as the digital element of the product is an enabler behind a service. While the software can be copied, a service is more difficult to emulate because it often incorporates non-digital elements. The authors introduce a digital SC framework by outlining some current physical and digital supply chain integration and distribution examples and by determining likely innovative supply chain scenarios on how these strategies might develop over the coming years.

Thus, this chapter examines the role of physical and virtual supply chain innovation strategies in electronic device supply chains by exploring the commonalities and differences between the design, manufacturing, and distribution models of digital and physical elements. The aim is to identify to what extent such strategies can be employed for engineer-to-order (ETO) supply chains. Gosling and Naim (2009) see ETO as a supply chain where the decoupling point is located at the design phase of a product. Integration between design and downstream supply chain activities is paramount.

\section{BACKGROUND}

Research in operations management, marketing and supply chain management has predominantly studied the relationships between upstream manufacturers and downstream retailers in supply chains for physical goods (Chellappa \& Shivendu, 2003; Padmanabhan \& Png, 1997). Physical goods are so defined because they obey physical laws. They possess mass and occupy volume. Over time, they can break down and degrade. It is not possible to create products without first sourcing appropriate materials. Energy (which also needs to be sourced) is expended in transformation and transportation. It could be said, therefore, that a large proportion of SCM has to do with overcoming the constraints imposed by physics on the products under consideration. 
However, with the rise of information and communication technology (ICT), not all products can be longer considered physical in the traditional sense of word. An increasingly important class of products, described variously as digital products, virtual goods or information goods (Shapiro \& Varian, 1999) has emerged that cannot be considered physical in the traditional sense of the word. Surprisingly, little is known about digital product supply chains, where products such as software, movies, music and newspapers are created, stored and delivered in a digital form over a network (Chellappa, 2000).

The chapter begins with giving n outline of ETO. It then goes on to investigate the properties of physical products and examines how these properties influence the supply chain. It then contrasts physical products with digital products such as software. The chapter ends by outlining some innovative integration strategies and how they can be employed in an ETO context.

\section{ETO AND THE MOVE TO MASS CUSTOMISATION}

Various definitions of Engineer-to-Order (ETO) exist in literature. ETO is a type of manufacturing process for highly customized products, which are required to be designed and engineered in detail as per the specifications in the order placed by customers (Pandit \& Zhu, 2007). The challenge for ETO supply chains stems from the social, technical and economic difficulty of synergising various parties along the supply chain. Hicks et al. (2000) point out that a typical ETO manufacturing process can be defined as a supply chain. Design and project management are considered to be core competencies in most ETO organisations. Pandit and Zhu (2007) argue that some of the most common problems that ETO supply chains are facing are difficulties in estimating lead-times, delivery dates, extensive rework due to late realisation of errors, poor product quality and material wastage, as well as conflicts between project and manufacture schedules. Most of those challenges are caused due to inefficient and ineffective information sharing among supply chain partners. Elfving (2003) found that long lead times in particular has more than half of its causes associated directly or indirectly with the design phase. Some examples can be summarised under the following: tedious collection and poor reliability of design input, changes due to early commitment and lack of knowledge, changes due to design error, coupling ETO product design to other systems design, outdated practice of auxiliary design and approvals, and complexity requiring large number of specialists.

Haug, Ladeby, Edwards (2009) define engineering companies that deliver products, which are engineered to specific requirements of their customers as ETO companies. Thus, they researched the potential transition of ETO companies towards mass customisation. Wikner and Rudberg (2005) propose a framework where they decouple the engineering and the design aspect ETO supply chains and are hence able to differentiate between manufacturing approaches (see Figure 1). This so called customer order decoupling, or order penetration point defines where in the manufacturing process a product is linked to a customer order. Wikner and Rudberg (2001) identified four main order penetration points: Engineer-to-order (ETO), Make-to-order (MTO), Assemble-to-order (ATO), and Make-to-Stock (MTS). One particular trait of ETO is that the engineering work has to be done for each order, while for the other strategies, the engineering work have already been carried out, meaning the product design is already 'in stock' before a customer order. 
Figure 1. Customer Order Decoupling Point Concept, (Rudberg and Wikner, 2004)

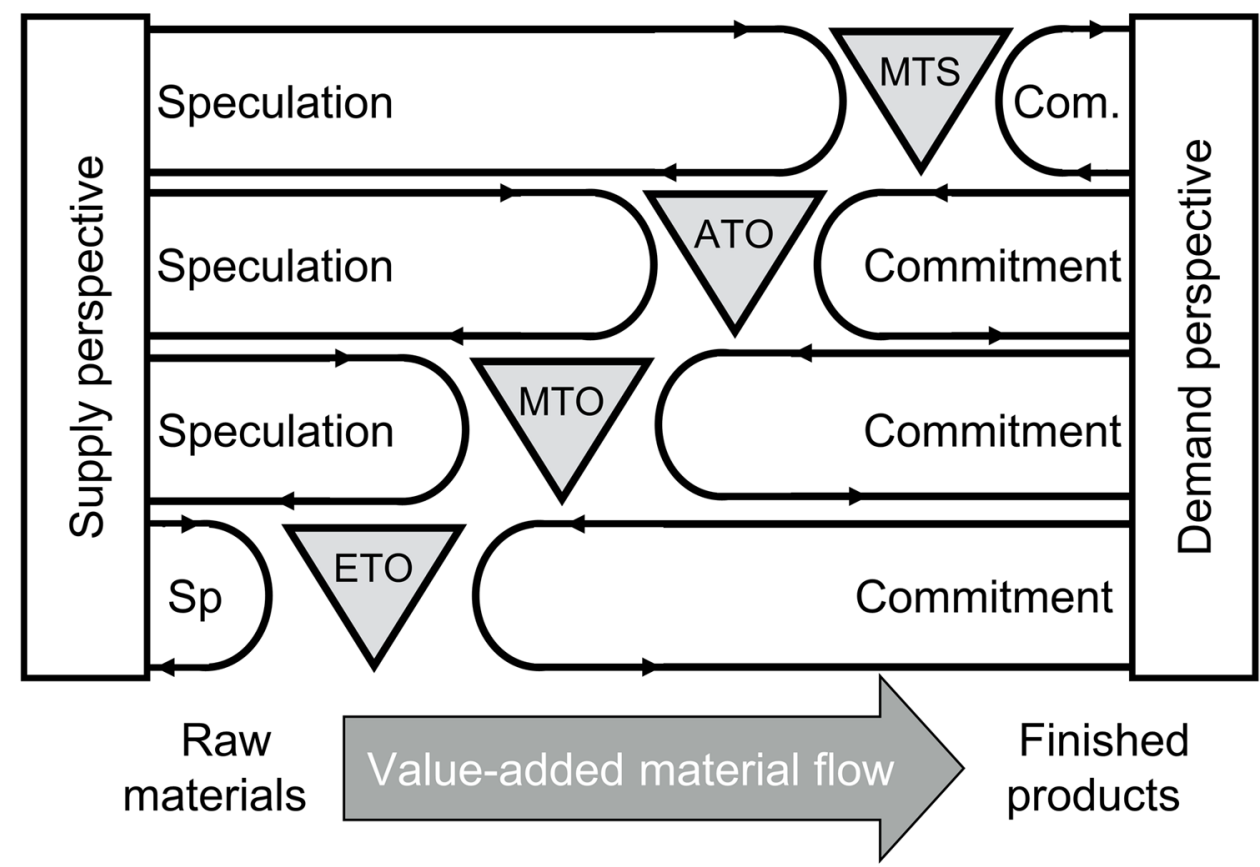

Literature discusses the move of some organisation from ETO companies to having become mass customizers. In particular, the increasing demand for more customized products sees mass customisation as a natural step from mass production for many organisations. According to Haug, Ladeby, Edwards (2009) the motivation for an ETO organisation to move towards mass customization is a decision based on many factors. They emphasize that an ETO company that moves towards mass customisation will have standardise their engineering work, which means that these companies need to reach a ETS (Engineer-to-Stock) state by being able to define parts of the solution space before receiving specific customer requirements. This implies some sort of a postponement of the customer order decoupling point. This can reduce delivery times, lead to more precise cost calculations, reduced specification and manufacturing costs, less training needed, and less errors, among other benefits. Mass customisation can be defined as "the ability to provide customized products or services through flexible processes in high volumes and at reasonably low cost" (Silveira et al., 2001). Piller (2004) goes one step further and defines mass customisation as a "customer co-design process of products and services, which meet the needs of each individual customer with regard to certain product features." To summarise, Haug, Ladeby and Edwards' (2009) research points out that some ETO companies move to mass customisation for parts of their product portfolio. This implies that such companies need to move the time of differentiation closer to the time of delivery.

In addition, in ETO, decisions as to what is to be digitized and what is to be part of the physical design need to be considered at the very beginning. For a smart phone, the casing, lenses, switches, and touchscreens will encompass the physical design, while installed apps, the operating system and firmware 
(e.g. the camera management system) will be components in the software design. For automotive products such as cars, digital systems such as stability control, climate control, engine management and safety systems are an increasingly important part of the value proposition. Software allows greater flexibility in how physical components will operate in the field - often beyond what can be anticipated during the design stage - and this presents new challenges as to how to software should be managed throughout its lifecycle and beyond the point of sale.

The following sections examine the role of physical and virtual supply chain innovation strategies in electronic device supply chains by exploring the commonalities and differences between the design, manufacturing, and distribution models of digital and physical elements. Based on this, the chapter will conclude with a brief analysis to what extent such strategies can be employed for engineer-to-order (ETO) supply chains.

\section{PHYSICAL VS. DIGITAL SUPPLY CHAINS}

Practitioners are familiar with physical product supply chains, in that they must overcome the basic laws of physics in order to distribute products to customers in a timely fashion. Physical products are composed of atoms, located at a particular place in space and time. They cannot typically be created virtually: they must be sourced from somewhere through processes such as farming or mining, and created through manufacturing processes. The aim of supply chain management is to move these physical entities (transportation management), re-constitute them (manufacturing), store them (warehouse management) and make the products available (distribution), all the while taking into consideration the amount of time and energy requirements necessary to achieve the desired outcomes. Overcoming such physical constraints requires extensive knowledge in disciplines ranging from forecasting, planning, procurement, cost management, manufacturing and engineering. All of this is overlaid by complex IT management systems. The limitations of physical products are furthermore constrained by the Second Law of Thermodynamics, which states that all items have a tendency to break down, tarnish or spoil over time. This requires the need for comprehensive maintenance processes and reverse logistics processes such as recycling, refurbishment, salvage and scrapping.

A number of different definitions of supply chains and their effective management exist in literature. Supply Chain Management in a traditional sense is concerned with the strategic management of a firm's activities, which together provide customers with the appropriate level of service at optimum cost (Christopher, 2005; Lambert et al., 1998; Sweeney et al., 2005). Chou and Ruchika (2006) note that in short, the aim of all entities in a supply chain is to ensure that a product moves down the chain in the most effective manner, so as to maximise profits earned by the whole chain as well as minimise wastage of raw materials, labour and time. Simchi-Levi et al. (2000, p.1) define supply chain management (SCM) as "a set of approaches utilised to effectively integrate suppliers, manufacturers, warehouses, and stores, so that merchandise is produced and distributed at the right quantities, to the right locations, and at the right time in order to minimise system-wide costs while satisfying service level requirements". It traditionally focuses on the hardware (material or goods) flow and the related information flow (Chou 
\& Ruchika, 2006) that can be both upstream and downstream. Within a supply chain, upstream suppliers provide input; the company then adds value to these inputs, before passing them downstream to the next actor, which can be either another company or the end user (Porter, 1985). The effective management of a supply chain transforms it into a value chain, where organisations tied in it derive a number of benefits (Baltacioglu et al., 2007). Traditionally, a value chain is the combination of nine generic value-added activities that provide (product and service) value within an organisation to be passed on to a customer. However, Ramsay (2005) notes that value is a perceived quality that is associated with the benefits that can occur at various points along a supply chain. Thus, value chains can operate in both directions.

Sweeney (2005) lays down four fundamentals of Supply Chain Management, citing problems with existing definitions of Supply Chain. These fundamentals are as follows:

1. Objectives: The objectives are to achieve high levels of customer service while optimising total supply chain investment and cost. Customer service, in effect, sets the specification for the supply chain and there is a strong focus on eliminating non-value-added activities in order to achieve this.

2. Philosophy: The success by which organisations can deliver products and services to customers is determined by the weakest link in that chain. It's not companies that compete with other companies, but supply chains competing with supply chains.

3. Flows: There are three key flows in any supply chain that need to be managed in a holistic manner. These are a) materials, b) information and c) money.

4. Relationships: This holistic approach requires that the participants in that supply chain look at each other differently. Confrontational approaches introduce inefficiencies and cause the entire supply chain to work sub-optimally. Relationships based on sharing and trust are required instead.

The concept of Supply Chain Management arose from the area of logistics, first of all focusing on the management of cost, then through the achievement of customer service improvements using advances in information technology, and in later years entering into management consciousness as a key strategic driver for businesses (Gattorna \& Walters, 1996). Supply Chain Management has allowed for "new breeds" of companies to emerge, that use their ability to supply products efficiently to act as a competitive weapon, with companies like Dell, Amazon and 7-Eleven (Chopra \& Meindl, 2001) emerging as major players on the global scale through highly innovative uses of Supply Chain Management techniques and technologies. As supply chains become ever more complex, due in part to outsourcing and today's global competitive environment, the way in which companies are structuring and managing their relationships can make the difference between profit and loss (Christopher \& Towill, 2002). In particular, globalization of supply chains creates logistical problems along three dimensions, which are replenishment level, time, and distance (McCullen \& Towill, 2000). In addition to that, customer choice and the nature of the product often implies that "one size does not fit all" (Shewchuck, 1998).

In contrast to physical products, digital products refer to any goods or services that can be digitised, which means converted into a binary format (Hui and Chao, 2002). They can be compressed without losing much information or quality. Thus, digital copies have a technical quality similar to the original (Peitz \& Waelbroeck, 2003). Whinston et al. (1997) identifies three properties of digital goods: 
- Indestructibility (the tendency of a digital product to maintain its form ad-infinitum).

- $\quad$ Transmutability (the ease by which a digital product can be modified).

- Reproducibility (the ease by which digital products can be reproduced, stored and transferred).

From an SCM perspective it is the property of reproducibility in particular that makes digital products so different from physical products. It has huge consequences so long as there is sufficient storage and bandwidth available to copy, move and transport the product (Eldering et al., 1999; Grochowski and Halem, 2003). Traditionally, beside the cost of material, pricing strategies of physical goods has always been based on factors such inventory cost and return policies (Chellappa \& Shivendu, 2003). For digital products, no raw materials or energy need to be sourced or used up in the process and replication is instantaneous. Moreover, digital products have almost zero marginal cost (Shapiro \& Varian, 1999; Whinston \& Choi, 1997) because they suffer neither from storage costs nor can they be returned for a salvage price.

Digital products constitute items such as movies, music, e-books, videos, podcasts, documents, apps and computer programs, reports and packages of diagnostic information. Such products normally exist as bits inside a wider physical architecture such as servers or electronic devices such as computers and smartphones. New digital products can be created simply by duplicating bits inside such architectures, with no requirement in most cases now for the creation of new physical media to support this process. (In the past, with CD ROMs and magnetic tape, this requirement did exist to a large extent). The creation of a new movie inside a server does not require any change to the atoms in that computer, merely a change of electronic state in a small part of its circuitry. The structuring of such bits is determined by developers and product creators, but once the final version is available, duplication is trivial. Transportation of the bits to the customer is relatively trivial also. Bits do not expend significant amounts energy in moving from source servers to their destinations. Neither do they require significant amounts of time, as the transfer processes are relatively instantaneous, or at least largely governed by the bandwidth speeds from source to delivery.

Managing the supply chain in traditional markets mainly provides challenges related to cost-effectiveness and physical barriers. By contrast, in a digital marketplace supply chain management encounters barriers that are not physical but rather strategic in nature (Nath, Saha \& Salehi-Sangari, 2007). Chou and Ruchika (2006) argue that a digital supply chain is a supply chain where the digital product constitutes a significant part of the total value of the product and where goods are not physically flowing through the supply chain. In a software supply chain, for example, a significant proportion of the supply chain is comprised by only one entity, which is usually one single company handling the design, development and production of a software product. It is usually at the distribution stage that a software company might engage the services of another company to market its product. Moreover, channel coordination policies such as returns are not applicable in the digital world. They do not need to be sent back for repair or rework like physical products do. So long as the physical device that enables the product runs correctly, so too will the digital asset.

Table 1 summarises the differences between digital and physical products by their characteristics. 
Physical and Digital Integration Strategies

Table 1. Difference of Physical and Digital Products

\begin{tabular}{|l|l|l|}
\hline & \multicolumn{1}{|c|}{ Physical } & Digital \\
\hline Composition & Atoms & Bits \\
\hline Environment & Physical Resources & Computer Architectures \\
\hline Availability & Limited by physical supply & Limited by bandwidth \\
\hline Ease of manufacture & Difficult & Trivial \\
\hline Speed to Market & Days, Weeks, Months & Seconds, Minutes \\
\hline Energy Requirements in Manufacturing & Significant & Insignificant \\
\hline Energy Requirements in Transportation & Significant & Insignificant \\
\hline $\begin{array}{l}\text { Human Involvement in Manufacture / } \\
\text { Transportation }\end{array}$ & Significant & Insignificant \\
\hline Costs & Significant \% of product value & Almost zero \\
\hline
\end{tabular}

\section{DIGITAL PRODUCT SUPPLY CHAIN FRAMEWORK}

Managing the supply chain in traditional markets mainly provides challenges related to cost-effectiveness and physical barriers. By contrast, in a digital marketplace supply chain management encounters barriers that are not physical but rather strategic in nature (Nath, Saha \& Salehi-Sangari, 2007). Chou and Ruchika (2006) argue that a digital software-focused supply chain is a supply chain where the digital product (software) constitutes a significant part of the total value of the product and where goods are not physically flowing through the supply chain. In a software supply chain, for example, a significant proportion of the supply chain is comprised by only one entity, which is usually one single company handling the design, development and production of a digital product. It is usually at the distribution stage that such a company might engage the services of another company to market its product. Moreover, channel coordination policies such as returns are not applicable in the digital world.

In order to outline the differences of a traditional and digital supply chain, and to describe a distinctive distribution framework, certain characteristics that determine a supply chain need to be contrasted. Hardaker and Graham (2001) have identified four interrelated dimensions that are involved in designing a supply chain, which are: (1) activities within a SC; (2) actors within a SC; (3) SC governance and (4) $\mathrm{SC}$ co-ordination. Thus, the authors held a number of in-depth, one-on-one interviews with practitioners in 7 companies with a significant software and electronic device business and that predominantly supply to enterprise customers on a global scale. The nature of our research was to look at some contemporary hybrid supply chains to understand key characteristics of the distribution approach. The companies examined are outlined in Table 2.

All companies are involved in the manufacture and distribution of electronic equipment that has both a software and a hardware component. Interviews were conducted with the above companies to understand how their supply chains were structured. The companies were a mix of consumer market suppliers and suppliers to the enterprise market, but it can be seen that the software distribution approach was quite 
Table 2. Company Description

\begin{tabular}{|l|l|}
\hline \multicolumn{1}{|c|}{ Company } & \multicolumn{1}{c|}{ Description } \\
\hline A & Supplier of network computing solutions, including servers, storage, software, and services \\
\hline B & $\begin{array}{l}\text { Organisation engaged in the development and manufacture of advanced information technologies, including } \\
\text { computer systems, software, storage systems, and microelectronics. }\end{array}$ \\
\hline C & $\begin{array}{l}\text { Organisation engaged in the development, manufacture, licensing, and support of software products for various } \\
\text { computing devices. }\end{array}$ \\
\hline D & $\begin{array}{l}\text { Organisation engaged in the development, delivery, and support of information infrastructure technologies and } \\
\text { solutions. }\end{array}$ \\
\hline E & Supplier of information, and care management products and services for the healthcare industry. \\
\hline F & $\begin{array}{l}\text { Organisation engaged in the design, manufacture, and marketing of computing systems and devices and related } \\
\text { software, services, peripherals, and networking solutions. }\end{array}$ \\
\hline G & Supplier of high-quality tool, diagnostic and equipment solutions for professional tool and equipment users. \\
\hline
\end{tabular}

similar irrespective of the nature of the customer base. Almost all used a mixed distribution approach. Companies bundled software with the original hardware sale, but when new software or software updates are being distributed, there is a tendency to distribute over the Internet. Table 3 summarises our findings.

These four dimensions identified by Hardaker and Graham (2001) will be used in the following to establish idiosyncratic features of combined hardware and software supply chains and describe unique digital distribution patterns apparent in the software industry based on the interviews.

\section{Dimension 1: Supply Chain Activities and Software Distribution}

The structure of activities is related to the natural sequence of processes inherent in a supply chain. In many industries, activities can be serially interdependent (Hardaker \& Graham, 2001). The traditional software product supplied by physical means, such as a CD represents such a structure. Chou and Ruchika (2006) have identified several stages of a software planning and production process. A cycle time up to three years could be required. The first three stages of the process involve design and development and testing of the software. The next three stages involve preparing the support infrastructure that accompanies the main software product. This might include a user-guide or documentation, media production and other add-on features, as well as the final product rollout. Finally, marketing and distribution, as well as retailing efforts to sell the software ensue (see figure 2).

In the increasingly digitised software industry supply chain, the flow of material is declining in importance, due to the availability of the Internet as a free distribution medium. Our research has elicited that a digital product can be characterised as a movement of value instead. Thus, key flows represent information, ideas and innovation, from requirements into development, from release through to distribution and finally to the end-consumer. As such, information is shared mainly through electronic means within and outside of an organisation. Moreover, network technologies have the potential to transform the supply chains of many industries because of the abolition of the trade-off between richness and reach of 
Physical and Digital Integration Strategies

Table 3. Summary of Company Characteristics

\begin{tabular}{|c|c|c|c|c|c|c|c|}
\hline & $\mathbf{A}$ & B & C & D & $\mathbf{E}$ & $\mathbf{F}$ & G \\
\hline Hardware & $\mathrm{Y}$ & $\mathrm{Y}$ & $\mathrm{Y}$ & $\mathrm{Y}$ & $\mathrm{Y}$ & $\mathrm{Y}$ & $\mathrm{Y}$ \\
\hline Software & $\mathrm{Y}$ & $\mathrm{Y}$ & $\mathrm{Y}$ & $\mathrm{Y}$ & $\mathrm{Y}$ & $\mathrm{Y}$ & $\mathrm{Y}$ \\
\hline Customer & $\begin{array}{l}\text { Consumer \& } \\
\text { Enterprise }\end{array}$ & Enterprise & $\begin{array}{l}\text { Consumer \& } \\
\text { Enterprise }\end{array}$ & Enterprise & Enterprise & Consumer & Enterprise \\
\hline $\begin{array}{l}\text { Separate } \\
\text { software } \\
\text { distribution } \\
\text { from hardware }\end{array}$ & $\mathrm{Y}$ & $\mathrm{Y}$ & $\mathrm{Y}$ & $\mathrm{Y}$ & $\mathrm{Y}$ & $\mathrm{Y}$ & $\mathrm{N}$ \\
\hline $\begin{array}{l}\text { Internet } \\
\text { Distribution }\end{array}$ & $\mathrm{Y}$ & $\mathrm{Y}$ & $\mathrm{Y}$ & $\mathrm{Y}$ & $\mathrm{Y}$ & $\mathrm{Y}$ & $\mathrm{N}$ \\
\hline $\begin{array}{l}\text { Initial } \\
\text { distribution } \\
\text { method }\end{array}$ & $\begin{array}{l}\text { Physical with } \\
\text { H/W }\end{array}$ & $\begin{array}{l}\text { Physical with } \\
\text { H/W }\end{array}$ & $\begin{array}{l}\text { Boxed S/W } \\
\text { and Internet }\end{array}$ & $\begin{array}{l}\text { Physical with } \\
\text { H/W }\end{array}$ & $\begin{array}{l}\text { Physical with } \\
\text { H/W }\end{array}$ & $\begin{array}{l}\text { Physical with } \\
\text { H/W }\end{array}$ & $\begin{array}{l}\text { Physical with } \\
\text { H/W }\end{array}$ \\
\hline $\begin{array}{l}\text { Internet } \\
\text { Distribution } \\
\text { of New SW to } \\
\text { Install Base }\end{array}$ & $\mathrm{Y}$ & $\mathrm{Y}$ & $\mathrm{N}$ & $\mathrm{N}$ & $\mathrm{Y}$ & $\mathrm{Y}$ & $\mathrm{N}$ \\
\hline $\begin{array}{l}\text { Distribution } \\
\text { of Updates } \\
\text { over Internet }\end{array}$ & $\mathrm{Y}$ & $\mathrm{Y}$ & $\mathrm{Y}$ & $\mathrm{Y}$ & $\mathrm{Y}$ & $\mathrm{Y}$ & $\mathrm{N}$ \\
\hline $\begin{array}{l}\text { Distribution } \\
\text { of Updates } \\
\text { by physical } \\
\text { means }\end{array}$ & $\mathrm{Y}$ & $\mathrm{N}$ & $\mathrm{Y}$ & $\mathrm{Y}$ & $\mathrm{Y}$ & $\mathrm{N}$ & $\mathrm{Y}$ \\
\hline $\begin{array}{l}\text { Nature of } \\
\text { Internet } \\
\text { distribution }\end{array}$ & DL & DL & $\begin{array}{l}\text { DL / } \\
\text { Streaming }\end{array}$ & DL & DL & DL/Streaming & CD-ROM \\
\hline $\begin{array}{l}\text { Multiple } \\
\text { platforms }\end{array}$ & $\begin{array}{l}\text { Yes - } \\
\text { Proprietary \& } \\
\text { nonprop }\end{array}$ & $\begin{array}{l}\text { No - } \\
\text { Proprietary }\end{array}$ & $\begin{array}{l}\text { Yes - } \\
\text { Proprietary } \\
\& \text { nonprop }\end{array}$ & $\begin{array}{l}\text { Yes - } \\
\text { Proprietary } \\
\text { \& nonprop }\end{array}$ & $\begin{array}{l}\text { Yes - } \\
\text { All non- } \\
\text { propietary }\end{array}$ & $\begin{array}{l}\text { Yes - } \\
\text { proprietary \& } \\
\text { non-proprietary }\end{array}$ & $\begin{array}{l}\text { No- } \\
\text { Proprietary }\end{array}$ \\
\hline $\begin{array}{l}\text { Software } \\
\text { Revenue } \\
\text { Process }\end{array}$ & $\begin{array}{l}\text { Subscription } \\
\text { based }\end{array}$ & $\begin{array}{l}\text { Subscription } \\
\text { based }\end{array}$ & $\begin{array}{l}\text { Pay per new } \\
\text { s/w purchase }\end{array}$ & $\begin{array}{l}\text { Pay per new } \\
\text { s/w purchase }\end{array}$ & $\begin{array}{l}\text { Subscription } \\
\text { based }\end{array}$ & Free & $\begin{array}{l}\text { Pay per new } \\
\text { s/w purchase }\end{array}$ \\
\hline $\begin{array}{l}\text { Secure } \\
\text { Distribution }\end{array}$ & $\begin{array}{l}\text { Temporary } \\
\text { weblinks }\end{array}$ & $\begin{array}{l}\text { Temporary } \\
\text { weblinks }\end{array}$ & Licence Key & License Key & None & None & $\begin{array}{l}\text { CD with } \\
\text { License Key }\end{array}$ \\
\hline
\end{tabular}

Figure 2. Software Supply Chain Activities and Processes

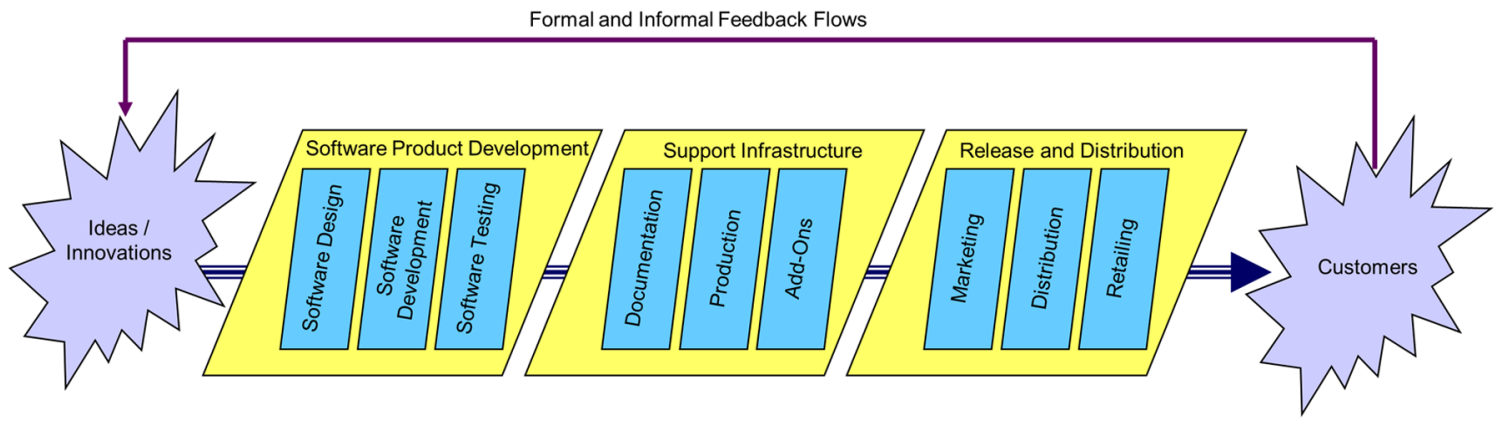


information, which means that everybody can communicate with everybody at almost zero cost, without constraints on the richness of information. (Graham et al., 2004 cite Evans \& Wurster, 1997). Richness of information includes characteristics such as bandwidth, customisation, and interactivity. Reach is defined as the connectivity, and is the number of agents involved in exchanging information. Before the Internet, to reach large numbers of people with rich information was a costly and time-consuming process. Traditionally, information could only be transferred in the form of a physical carrier such as a document, book, CD, etc.; it could not travel by itself. Therefore, costs and physical constraints limited the size of the audience to which the information could be sent and the nature of the information itself (Graham et al., 2004).

The Internet has an important impact on how software is distributed. Through the interviews three major distribution characteristics could be identified: (1) Physical and pseudo-physical distribution; and (2) free distribution.

\section{Pseudo-Physical Distribution}

3 out of the 7 interviewed companies have chosen to pursue the first approach: born out of supply chains, legacy infrastructures and a competitive landscape that was designed to deal with physical product manufacture. Companies pursuing this strategy act to limit supply through technological copy protection measures backed up by legal enforcement. The customer's use of the software is impaired from the outset by highly restrictive licenses that need to be agreed to before the product can be used at all. Then, copy protection measures such as activation keys are included in the software to prevent duplicate copies being made. Complex supply chains need to be developed to support many of these initiatives. For instance, an infrastructure may be required to distribute activation keys in a secure fashion to the correct customers. These processes are complicated where third parties (distributors or resellers) need to be involved. Billing mechanisms may need to be integrated with the distribution mechanisms. Such processes require significant customer support overhead.

\section{Free Distribution}

In the second approach, few or no controls are imposed on the distribution of software. Some or all versions of the software are distributed to users with few control mechanisms in place. Although 3 of respondents offered free distribution of some sort, a number of different approaches were used:

1. The total-service based model. In this model, the software is free to distribute and install. However, associated services such as consultancy, bug fixing, hardware, training, technical support and customer support (all limited in supply) are available to the customer for a fee.

2. The customised model. In this case, the software is freely distributed. However, the nature of the software is that without extensive customisation, it has little value except to the customer for which it is intended. The companies involved deliver large-scale system installations, where the software requires extensive modification before it can be useful to the customer.

3. The complementary model. In this case the software is provided to enhance the value of a physical product such as computer hardware. 
Physical and Digital Integration Strategies

\section{Dimension 2: Supply Chain Actors}

This dimension means the level of dynamism in the choice of actors in a supply chain (Hardaker and Graham, 2001). The chain is seen as very static when actors are relatively established. On the other hand it is very dynamic, when actors vary from one market opportunity to another. There are various levels of flexibility in the choice of partners in-between. (Graham, Burnes, Lewis, \& Langer, 2004). Traditionally, the software industry has been dominated by a few well-established major players and thus has been very static in character. Chou and Ruchika (2006) argue that most stages of the traditional software supply chain framework is taking place in-house and decisions to outsource are only made when production and distribution is infeasible in-house due to investment constraints. Thus, a small supply chain is less complex than having a variety of different actors. Therefore, it can be seen that little effort is being made in liaising with a wide array of partners with regards to inventory management throughout the supply chain. This also ensures that profits stay in-house rather than being shared with additional actors within the chain.

As outlined above, the Internet is eliminating the need for physical distribution and the retail of software products and has let to the invention of new forms of distribution for software products. All interviewees highlighted that it facilitates communications between the different actors. Moreover, new online portals have entered the online market providing download capabilities for a wide range of software products. As such, the traditional software supply chain is developing into a more dynamic marketplace, allowing new start-ups to market and distribute their products at a low cost point. However, our interviews revealed that poor management of internal and external relationships within a software network could have a detrimental effect on supply chain performance. Relationship management becomes ever important, especially in the software distribution process. Many software companies collaborate together to produce customer deliverables and a much stronger customer interaction is advocated, than it has been with physical supply chains.

\section{Dimension 3: Supply Chain Governance}

This relates to the ownership and the control of various actors in the supply chain. Dyer (2000) argues that in line with transaction cost theory (Williamson, 1979), three alternatives for governing a transaction or supply chain relationship exist: (1) vertical integration; (2) arm's length relationship; and (3) partnerships. In a vertically-integrated supply chain the organisation that commissions other organisations to help create the final software product is the main force in the supply chain and controls as such key channels and value steps; at the extreme, a company would produce all inputs itself. This is opposed to independent parties that operate at arm's length relationships (Graham, Burnes, Lewis, \& Langer, 2004), which mean that a company buys inputs from outside through short-term suppliers for the best conditions each time an input is required. The concept of partnership, by contrast, means that a company sources from a small number of suppliers by building co-operative and long-term relationships (Dyer, 2000). If transaction costs are high, it is more favourable to own suppliers and distributors and as such produce in-house. On the other hand, if transaction costs are low, it is more favourable to outsource and procure materials and services. 
Traditionally, the software supply chain has been characterised by a small number of very powerful companies that control all aspects of the software supply chain, from creation to test to distribution and installation. Companies such as Microsoft and SAP have made use of supply side economies of scale (availability of trained developers and IP), plus demand side economies of scale (customer lock-in and network effects) to achieve disproportional market shares, effectively pushing out the competition. To a large extent, such effects are still in play, although our interviews elicited that incumbents have to increasingly deal with new development models and revenue models that are resulting in a shift in the power dynamics of the industry. The rise of Open Source development (Hars \& Ou, 2002) has enabled communities of programmers, motivated by non-financial incentives, to challenge commercial incumbents (e.g. Mozilla Firefox, Linux, Apache Tomcat). The movement of revenue from pay-per-unit business models to advertising business models has seen companies such as Google begin to challenge powerful companies such as Microsoft, particularly on the consumer side of the business.

\section{Dimension 4: Supply Chain Coordination}

Sweeney (2007) depicts that managing information flows in the supply chain is one of the most crucial activities in supply chain management as the flow of materials and money is usually initiated by information movements. Hardaker and Graham (2001) reinforce this by outlining that co-ordination in a supply chain occurs through the communication of orders, stock level and demand feedback. Poor information flows essentially leads to the so-called bullwhip-effect that requires holding excessive levels of inventory. As such, high demand visibility plays a strategic role in reducing inventory levels (Sweeney, 2007). Thus, network-based communication structures in a supply chain might offset these effects.

The new co-ordination scenario surrounding Internet distribution is much different. Our interviews highlighted that in some respects co-ordination is less of an issue as the latest product can always be picked up by just clicking on a web-link, and because there is an abundance of copies to pick up, there are no critical inventory or purchasing issues to contend with. Companies that wish to retain control over their software through restrictions to copying have to contend with more complex co-ordination challenges, e.g. the supply of activation keys and the monitoring of software assets remotely to ensure that copyright is not being breached. Many companies we interviewed are not interested in the extra overhead associated with such oversight.

To summarise the above, the method of distributing new software to the existing hardware base tended to correlate with the software revenue process. If new software was free of charge or if a support contract was in place via subscription, there was a tendency to use Internet update mechanisms as a primary means of distribution. If there was an up-front license charge for new software, physical distribution mechanisms were more commonplace. For software updates, almost all respondents tended to use an Internet distribution framework. Only in one case, Company G, distribution of updates was purely physical. This is because an Internet distribution infrastructure had not yet been built for the company at this time. Updates and bug-fixes were difficult to distribute and therefore every possible effort was made to ensure the products were tested thoroughly before release. What was interesting was that for many companies, physical distribution mechanisms were in place for software, even for updates. Many 
companies cited customer preference and concerns over Internet security. However, many of the companies were moving customers over to Internet distribution for updates because of the cost-efficiencies involved. Security around software distribution tended to be strongest where there was a pay-per-item software contract in place. In these cases, customers needed to activate a license key, which required a completely separate supply chain to distribute these keys to customers. In the case of subscription customers and free distribution, no such supply chain was required. Customers were given access to the new software via temporary web pages or password protected customer web-accounts. It is clear from our interviews that there was a clear advantage to companies in moving away from pay-per-item digital purchase mechanism and instead using subscription based mechanisms. Pay-per-item required complex licence management infrastructures, high security, Digital Rights Management (DRM) and payment mechanisms that we tied to the software sale. There was a greater tendency to rely on physical distribution compared to subscription. For subscription based or free distribution, the management systems were less complex and updates tended to be more regular. Subscription based companies also tended to be more comfortable with centralising software distribution - creating a specialised skill-base within the company for software distribution. This lead to standardisation and the implementation of strong processes with distributed hardware engineering teams. Pay-per-item companies tended to be less mature in terms of experience with software distribution.

For pure physical goods manufacturers or purely digital product producers, totally different strategies can be adopted to deliver products to end-customers. Traditional supply chains will continue to work for physical goods, while Internet based strategies can be exploited for digital products. There is a growing class of products that will require both physical and digital distribution strategies. These product contain hardware and software elements and they currently include computers, smart phones, smart TVs and various industrial equipment. As the "Internet of Things" continues to emerge we are seeing watches, lightbulbs, cars, glasses and cameras acquire internet capability. More and more products will feature these dual modes in the future. The demand for new electronic devices has not abated. The demand for devices has been spurred by new websites such as IndieGogo, that link the customer directly to new and innovative electronic product designs. This is a kind of ETO approach where informal investors take a financial stake in the product design.

To conclude, the differences between physical and digital supply chains outlined above are very large. This affects how we need to approach managing the supply chains for these types of products. Table 4 summarises the differences between digital and physical products by their supply chains.

The role of engineering is important for both product types. Even though the nature of the engineering may be somewhat different, good product design is a paramount consideration in all cases. Beyond that - in terms of distribution operations - there is a strong divergence. Sourcing of digital products is primarily a mental activity, driven by ideas. While ideas are important for physical products, raw materials must be purchased or extracted in order to commence the process. Beyond this, the logistics for digital products is Internet and server driven. The next section outlines the role of innovation in electronic device supply chains to illustrate the linkage of our findings with the theory of innovation. 
Table 4. SC Properties of digital and physical products

\begin{tabular}{|l|l|l|}
\hline & \multicolumn{1}{|c|}{ Physical } & \multicolumn{1}{c|}{ Digital } \\
\hline Design & $\begin{array}{l}\text { Materials Engineering, Electronic Engineering, } \\
\text { Mechanical Engineering, Chemical } \\
\text { Engineering, Food Engineering }\end{array}$ & $\begin{array}{l}\text { Software Engineering, Authoring, Development, } \\
\text { Game Development, Composing }\end{array}$ \\
\hline Sourcing & Mining, Farming, Forestry, Ideas & Ideas, Requirements \\
\hline Inbound Logistics & Trucking, Shipping, Air Freight & N/A \\
\hline Manufacturing & $\begin{array}{l}\text { Assembly, Process, Incubation, Germination, } \\
\text { Extraction }\end{array}$ & Duplication \\
\hline Outbound Logistics & Trucking, Shipping, Air Freight & Digital Networks \\
\hline Warehousing & Distribution Centres, Silos, Wholesalers, 3PLs. & Distributed Servers \\
\hline Distribution & Retail shops, Malls, Auctions, Online & Online, Streaming, Retail shops, Movie Theatres \\
\hline Reverse Logistics & Returns, Repair, Refurbishment, Re-purposing, & Version Management \\
\hline
\end{tabular}

\section{INNOVATIVE INTEGRATION STRATEGIES IN ELECTRONIC DEVICE SUPPLY CHAINS}

Innovation is generally considered to be one of the key drivers of corporate success (Cardozo et al., 1993). Modern definitions of supply chain management expand beyond the activities that are related to working capital as outlined in the traditional supply chain management definitions (Lummus et al., 2001). Innovative creation and promotion of value and the maximisation of this value over the longer term is becoming more and more critical elements in supply chain management (Wagner and Ryan, 2009). Supplier involvement and alliances are routes to innovation generation. The generation of an innovation typically occurs in the development phase of a new product. This includes the generation of initial ideas, their critical evaluation, the testing of derived concepts, the product development, and final launch (Crawford \& Di Benedetto, 2000). Roy, Sivakumar and Wilkinson (2004) argue that nevertheless, fundamental changes in the configuration of an existing product may as well be considered as radical for the affected supply chain members. If the innovations involving less radical or incremental changes entail for example quicker delivery periods, or reduction of material thickness and cost. Innovation generation in a supply chain context involves changes in product, process, or service that either reduce cost or improve efficiency.

In Roger`s (1995) seminal research the process is detailed how innovations move from one population to another and the role of key factors in the individual decision to adopt is discussed. In this context, Rogers (1995) defines adoption as "(...) the decision to make full use of an innovation as the best course of action available", while diffusion refers to the spread over time of an innovation within the unit or to other units. The explicit motivators for the organisational adoption and innovation diffusion are described by the following set of variables:

- Relative Advantage: The extent to which the innovation is perceived to have significant advantages over current alternatives. 
- Compatibility: The degree to which the innovation is seen as being consistent with past practices, current values and existing needs.

- Complexity: The extent to which the innovation can readily be understood and easily implemented.

- Trialability: New ideas that can be tried out at low costs before wholesale adoption are more likely to be taken up.

- Observability: The degree to which the use and benefits of the innovation are visible to others, and therefore act as a further stimulus to uptake by others.

In this context it is worthwhile to mention the theory of S-curve in innovation adoption (Rogers, 1995). It suggests that technologies are a conceptualisation of S-curve sequences that drive various new product introductions. The S-curve emerges because a new technology or product is rather limited to a small group of early adopters and small niche markets that derive benefits from this early introduction (Chandy \& Tellis, 2000). With its diffusion to a wider user group, the product or technology gains ascendancy and new capabilities are introduced and refined. During this middle phase a dominant allegiance of the product or technology in the market place emerges, which is effecting standardization from design to manufacturing. This in turn allows heightened competition as new entrants realize opportunities for further innovation based on cost and scale as well as product performance. This is the period of rapid and greatest growth. During the final phase the product reaches market saturation and hits a plateau. Successful companies begin to consolidate their market share, seek further economies of scale, but also shift focus by targeting other growth opportunities (Essa, 2005). Harrison and Waite (2005) therefore argue that the extent to which adoption of an innovation can yield a competitive advantage is relatively short-lived. As the innovation becomes more widespread, competitive advantage diminishes and innovation becomes a necessary competitive requirement. This means that new product development, its maintenance and updates need to be effectively and flexibly managed from the initial idea through to final delivery to the customer in a closed loop fashion. The management of closed innovation cycles is seen as a key component in sustaining competitive advantage within supply chains (Utterback, 1994; Tidd et al., 2005). Few companies have achieved mastery over their innovation cycles. Highly innovative companies are characterised by regular updates of new products and the ability to introduce new products that alter the basis of competition (Anthony et al., 2008). Fast evolving companies are for example electronic device manufacturers in the infotainment industry. The Internet in particular has accelerated this sectors' evolutionary speed and consumers of digital infotainment devices are experiencing a true revolution in the supply and distribution chains for many of such products. The reason for this rapid change can be attributed to groundbreaking developments in conductor technologies, such as increased transmission capacities in broadband, together with the evolution of so called boxes, including DVD players, digital recorders, digital TV decoders, music and video digital players, PDAs and digitally enabled mobile phones. This gave rise to develop hybrid devices that combine physical and digital product innovations to create a market-leading product idea, which is able to dictate the alignment of conductor and content providers to its own standards (Graeml, Engelbert \& Weiler, 2008). Graeml, Engelbert and Weiler (2008) describe Apple's iPod (box) and the iTunes (conductor) store as one such example.

Wagner and Ryan (2009) point out that digital product manufacturers must work with customers and developers in a tightly managed cyclical fashion. While original ideas may be generated internally within the developer network, once those ideas are transformed into products the customer takes a central role 
in the future direction of the product and the further changes that ensue from there. Within this extended concept, the role of partnership remains paramount. Product developers operate within complex webs and networks of players - engineers, product managers, developers, industrial designers etc. - each of whom need to work together to turn around new products quickly and efficiently. Information management is required to connect producers to customers, thus ensuring that the products meet changing customer requirements. A kind of reverse logistics flow needs to be factored into digital supply chain - the movement of customer feedback into the hands of the manufacturers in order to enable products to be updated and improved. Customer responses will inevitably form part of the development of subsequent versions of the product, so mechanisms that gather feedback from the customer, be it formal (for example, surveys or automated bug-reporting) or informal (for example, phone calls, emails, web postings), need to be in place. In essence the key to competition in the digital realm is not really a single sale, but the long-term relationship with the customer base and the securing of a profitable income stream over time.

Innovation cycles need to be incorporated when considering supply chains for products that require physical and digital elements. Changes required by customers from a software perspective may force modifications to the hardware. More commonly, changes in the hardware may require further software development and careful consideration of software roadmaps in the light of rapid advances in physical technology. Software and hardware developments need to be closely aligned for the lifecycle of the product because the customer may not be as concerned by the distinction between the two as the developers might be.

\section{INTEGRATION STRATEGIES FOR ETO COMPANIES}

Digital product manufacturers must work with customers and developers in a tightly managed cyclical fashion (Wagner \& Ryan, 2009). The ETO approach aligns with this perspective for many electronic products, if not at initial product design, then often during the development of new versions of the same product. While original ideas may be generated internally within the developer network, once those ideas are transformed into products the customer takes a central role in the future direction of the product and the further changes that ensue from there. A high degree of partnership is required, and processes that facilitate this partnership are essential. Information management is required to connect producers to customers, thus ensuring that the products meet changing customer requirements. A kind of reverse logistics flow needs to be factored into the digital supply chain - the movement of customer feedback into the hands of the manufacturers in order to enable products to be updated and improved.

New websites such as IndieGogo link the customer directly to new and innovative electronic product designs, which need to be transformed into usable and highly functional products in a short space of time. These products need to deliver not only high quality functionality, but also with well thought out software distribution and update mechanisms. ETO companies using bundled electronics will require software and hardware distribution mechanisms. Our analysis suggests that two separate strategies are important - one for physical distribution, the other for software distribution. While there needs to be a touchpoint at initial product sale, i.e. with the hardware getting the latest software prior to product shipment, from then the distribution strategies can diverge. 


\section{Physical and Digital Integration Strategies}

Relevant companies in the ETO space must consider the longer term aspects of supporting their install base, and in such cases they should be able to regularly provide new software and software updates to their customers. In circumstances where a software distribution strategy is not included, even if only for firmware bug-fixes, the risks to the company could be sizable. Our analysis sees clear benefits to companies in using Internet based distribution strategies for software. Our analysis also suggests that there are advantages in utilising a subscription mechanism for bundled software or distributing the software to customers for free. In either case the software distribution infrastructure is simpler and the customer experience is better. Where a pay-per-item licensing mechanism is required, costs will be significant and copyright protection / security will reduce customer satisfaction.

Companies using ETO are encouraged to use password-based web accounts with customers. This will assist with communications and sharing of information and specifications, etc. Through such accounts, new software and new software updates can be provided securely and safely to the customer install base and for a minimum of hassle. Within ETO companies, a centre of expertise for software distribution is recommended. Such a centre will concentrate skills and create standards around which hardware engineers can work effectively. It will facilitate a common approach to software distribution and help with Internet strategy development for the company as it expands into new products.

\section{FUTURE RESEARCH DIRECTION}

While this analysis mainly concentrated on software distribution within the context of electronics, future areas of research could include an examination of other types of digital product, e.g. movies, music and podcasts etc., to see if the recommendations still hold for such goods. A number of in-depth case-studies of mature ETO suppliers of electronic goods and electronic devices would provide additional insights into particular issues faced by these companies. The interfaces between hardware engineering and software engineering for mature ETO suppliers, particularly around the management of the launch and update process would be an interesting focus of further research.

\section{CONCLUSION}

The chapter has discussed the role of the Internet and how it has facilitated new modes of distribution and support for electronic products. Supply chains with a digital content have distinctive ways of being managed. Integration and innovation are important concepts in digital and hybrid supply chains. Digital product manufacturers must work with customers and developers in a tightly managed cyclical fashion. The Internet and the virtualisation of functionality means that electronically based ETO products need to accommodate a much greater degree of complexity that was traditionally the case. Software development and distribution, while separate from physical supply chains, need to integrate seamlessly at all stages of the process up to the eventual replacement of the product. 


\section{REFERENCES}

Anthony, S. D., Johnson, M. W., Sinfield, J. V., \& Altman, E. J. (2008). The Innovator's Guide to Growth: Putting Disruptive Innovation to Work. Boston, MA: Harvard Business Press.

Baltacioglu, E. A., Kaplan, M. D., Yurt And, O., \& Cem Kaplan, Y. (2007). A new framework for service supply chains. Service Industries Journal, 27(2), 105-124. doi:10.1080/02642060601122629

Cardozo, R., McLaughlin, K., Harmon, B., Reynolds, P., \& Miller, B. (1993). Product- market choices and growth of new businesses. Journal of Product Innovation Management, 10(4), 331-340. doi:10.1016/07376782(93)90075-2

Chandy, R. K., \& Tellis, G. J. (2000). The incumbent's curse? Incumbency, size, and radical product innovation. Journal of Marketing, 6(3), 1-17. doi:10.1509/jmkg.64.3.1.18033

Chellappa, R. K. (2000). Digital Products and E-Business. Marshall Magazine, Spring, 48-49.

Chellappa, R. K., \& Shivendu, S. (2003). Pay Now or Pay Later? Managing Digital Product Supply Chains. ACM International Conference Proceeding Series (Vol. 50, pp. 230-234).

Chopra, S., \& Meindl, P. (2001). Supply Chain Management: Strategy, planning and operation. Prentice Hall.

Chou, M., \& Ruchika, A. (2006). An in-depth study of the software supply chains. Proceedings of the IEEE International Conference on Industrial Informatics. doi:10.1109/INDIN.2006.275656

Christopher, M., \& Towill, D. R. (2002). Developing market specific supply chain strategies. International Journal of Logistics Management, 13(1), 1-4. doi:10.1108/09574090210806324

Crawford, C. M., \& Di Benedetto, C. A. (2000). New Product Management. Boston: McGraw-Hill.

Da Silveira, G., Borenstein, D., \& Fogliatto, F. S. (2001). Mass customisation: Literature review and research directions. International Journal of Production Economics, 72(1), 1-13. doi:10.1016/S09255273(00)00079-7

Dyer, J. H. (2000). Collaborative Advantage: Winning Through Extended Enterprise Supplier Networks. Oxford: Oxford University Press.

Eldering, C. A., Sylla, M. L., \& Eisenach, J. A. (1999). Is there a Moore's law for bandwidth? IEEE Communications Magazine, 37(10), 117-121. doi:10.1109/35.795601

Elfving, J. (2003). Exploration of opportunities to reduce lead times for engineering-to-order products [Ph.D. dissertation]. University of California, Berkley.

Essa, A. (2005). Innovation Life Cycle and the S-Curve. Retrieved from http://tatler.typepad.com/ nose/2005/11/innovation_life.html

Evans, P. B., \& Wurster, T. S. (1997). Strategy and the new economics of information. Harvard Business Review, 5, 70-82. PMID:10170332 
Gattorna, J. L., \& Walters, D. W. (1996). Managing the Supply Chain: A Strategic Perspective. Macmillan Business.

Gosling, J., \& Naim, M. M. (2009). Engineer-to-order supply chain management: A literature review and research agenda. International Journal of Production Economics, 122(2), 741-754. doi:10.1016/j. ijpe.2009.07.002

Graeml, A. R., Ebgelbert, R., \& Weiler, A. L. G. (2008, June 15-18). Understanding value chain strategies for the iPod through the perspective of Fine's evolutionary model. Proceedings of the 15th Annual International Conference of the European Operations Management Association (EurOMA), Gronigen, Netherlands.

Graham, G., Burnes, B., Lewis, G., \& Langer, J. (2004). The transformation of the music industry supply chain: A major label perspective. International Journal of Operations \& Production Management, 24(11), 1087-1103. doi:10.1108/01443570410563241

Grochowski, W., \& Halem, R. D. (2003). Technological Impact of magnetic hard disk drives on storage systems. IBM Systems Journal, 42(2), 338-346. doi:10.1147/sj.422.0338

Hardaker, G., \& Graham, G. (2001). Wired marketing: energizing business for e-Commerce. Chicester: John Wiley \& Sons.

Harrison, T., \& Waite, K. (2005). Critical factors affecting intermediary web site adoption: Understanding how to extend e-participation. Journal of Business and Industrial Marketing, 20(4/5), 187-199. doi:10.1108/08858620510603864

Hars, A., \& Ou, S. (2002). Working for Free? - Motivations for Participating in Open Source Projects. Proceedings International Journal of Electronic Commerce, 6(3), 25-39.

Haug, A., Ladeby, K., \& Edwards, K. (2009). From engineer-to-order to mass customisation. Management Research News, 32(7), 633-644. doi:10.1108/01409170910965233

Hicks, C., McGovern, T., \& Earl, C. F. (2000). Supply chain management: A strategic issue in engineer to order manufacturing. International Journal of Production Economics, 65(2), 179-190. doi:10.1016/ S0925-5273(99)00026-2

Hui, K. L., \& Chau, P. Y. K. (2002). Classifying Digital Products. Communications of the ACM, 45(6), 73-79. doi:10.1145/508448.508451

Lummus, R. R., Krumwiede, D. W., \& Vokurka, R. J. (2001). The relationship of logistics to supply chain management: Developing a common industry definition. Industrial Management \& Data Systems, 101(8), 426-432. doi:10.1108/02635570110406730

McCullen, P., \& Towill, D. R. (2000). Practical ways of reducing bullwhip: The case of the Glosuch global supply chain. International Journal of Operations Management, 26(10), 24-30.

Merrifield, D. B. (2000). Changing nature of competitive advantage. Research Technology Management, 41(1), 41-45. 
Nath, A. K., Saha, P., \& Salehi-Sangari, E. (2007). Transforming Supply Chains in Digital Content Delivery: A Case Study in Apple. In L. Xu, A. Tjoa, S. Chaudhry (Eds.), Research and Practical Issues of Enterprise Information Systems II (Vol. 2, pp. 1079-1089). Boston: Springer.

Padmanabhan, V., \& Png, I. P. L. (1997). Manufacturer's Returns Policies and Retail Competition. Marketing Science, 16(1), 81-94. doi:10.1287/mksc.16.1.81

Pandit, A., \& Zhu, Y. (2007). An ontology-based approach to support decision-making for the design of ETO (engineer-to-order) products. Automation in Construction, 16(6), 759-770. doi:10.1016/j.autcon.2007.02.003

Peitz, M., \& Waelbroeck, P. (2003). Piracy of Digital Products: A critical Review of the Economics Literature. CESifo Working Paper, No. 1071.

Piller, F. (2004). Mass customisation: Reflections on the state of the concept. International Journal of Flexible Manufacturing Systems, 16(4), 313-334. doi:10.1007/s10696-005-5170-x

Porter, M. E. (1985). Competitive Advantage. New York: The Free Press.

Porter, M. E., \& Stern, S. (2001). Innovation: Location matters. MIT Sloan Management Review, 42(4), $28-36$.

Ramsay, J. (2005). The real meaning of value in trading relationships. International Journal of Operations \& Production Management, 25(6), 549-565. doi:10.1108/01443570510599719

Rogers, E. M. (1995). Diffusion of innovations (4 ed.). New York: The Free Press.

Roy, S., Sivakumar, K., \& Wilkinson, I.F. (2004). Innovation generation in supply chain relationships: a conceptual model and research propositions. Journal of the Academy of Marketing Supply chainience, 32(1), 61-79.

Shapiro, C., \& Varian, H. (1999). Information Rules. Boston: Harvard Business School Press.

Shewchuck, J. P. (1998). Agile manufacturing: one size does not fit all. Proc. Int. Conference Manufacturing Value Chains, Troon (pp. 143-150). doi:10.1007/978-0-387-35321-0_16

Simchi-Levi, D., Kaminsky, P., \& Simchi-Levi, E. (2001). Designing and managing the supply chain: Concepts, strategies, and cases. New York: McGraw-Hill.

Sweeney, E. (2007). Introduction. In Perspectives on Supply Chain Management and Logistics - Creating Competitive Organisations in The 21st Century. Dublin: Blackhall Publishers.

Tidd, J., Bessant, J., \& Pavitt, K. (2005). Managing innovation: integrating technological, market and organizational change. Chichester: Wiley.

Utterback, J. M. (1994). Mastering the dynamics of innovation: how companies can seize opportunities in the face of technological change. Boston, MA: Harvard Business Press. 
Wagner, C., \& Ryan, C. (2009). Innovation Cycle Management of Digital Supply Chains. In E. Sweeney (Ed.), Supply Chain Management and Logistics in a Volatile Global Environment (pp. 169-182). Dublin: Blackhall Publishers.

Whinston, A. O. D., \& Choi, S. (1997). The Economics of Electronic Commerce. New York: Macmillan Publishing Company.

Wikner, J., \& Rudberg, M. (2001). On the customer order decoupling point (Working Paper No. WP284). Linkoeping Institute of Technology, Sweden.

Wikner, J., \& Rudberg, M. (2005). Integrating production and engineering perspectives on the customer order decoupling point. International Journal of Operations \& Production Management, 25(7), 623-641. doi:10.1108/01443570510605072

Williamson, O. E. (1979). Transaction cost economics: The governance of contractual relations. The Journal of Law \& Economics, 22(2), 233-261. doi:10.1086/466942 